\title{
BILATERAL CALCAREOUS BURSITIS AT THE ELBOW
}

\author{
Tibor Vizkelety and Karoly Aszodi, Budapest, Hungary \\ From the Department of Orthopaedics, ${ }^{*}$ University. Medical School, Budapest
}

A close correlation exists between the pathomechanism and localisation of calcareous bursitis and calcification of tendons and tendon sheaths. Recent descriptions emphasise this fact and give calcifying bursitis, tendinitis and paratendinitis the common name of periarthritis calcarea (Markó 1956, Bánki 1964). Calcareous bursitis is frequently encountered in the shoulder region but it is rarely found elsewhere. Eufinger (1957) mentioned only the subdeltoid bursa as being affected. Hamilton (1951) described thirteen cases of bursitis under the name of calcinosis; in six of his cases the shoulder was affected; in the rest other parts were involved.

Calcification of a bursa is viewed by pathologists as a dystrophic process (Anderson 1961). Deposition of calcium-holding material in the wall and cavities of the bursa is preceded by regressive changes in the tissues. The oxygen supply and nutrition of the walls of the bursa decrease with an increase of their calcium-holding capacity. According to Rabl (1923) increased carbon dioxide saturation of damaged tissues leads to calcium deposition. This occurs most commonly in infective and degenerative conditions.

Claessens and Faure (1963) divided bursitis into two major groups: post-traumatic and infective. Rheumatic bursitis belongs to the second group and includes cases in which bacterial infection cannot be proved. In the course of chronic inflammation the wall of the bursa thickens and in consequence of insufficient nutrition degenerative changes take place. Frequently inflammatory and degenerative changes are present simultaneously (Albertini 1929).

Para-articular calcification and ossification occur in neurotrophic disorders. Symmetrical bursitis (Günther 1913, Holzweissig 1925) and bilateral tendon calcifications (Albertini 1929) suggest a possible neurological basis for the lesions. Exner (1957) regarded neurovegetative dysfunction as a cause of pathological calcification. Other authors too (Gaule 1895, Meyer 1927, Seifert 1930, Katthagen 1949, Reischauer 1958, Rossak 1961, Waschulewski 1963) have described the relationship of abnormal calcification to an underlying neurological cause.

\section{CASE REPORT}

A boy aged eight came in January 1963. A painful swelling on the right elbow had been observed at the age of seven years, and a bursa was excised in another hospital. A sinus with serous discharge developed in the wound. When the boy was first seen by us there was a firm swelling on the back of the elbow. There was slight restriction of movement of the joint. Radiographs showed a lobulated homogeneous calcified mass behind the elbow and over the olecranon. Six months later the shadow was larger and lobulation increased (Fig. 1). A fluctuating mass the size of a plum was present. At operation in August 1961 a bursa 2 centimetres in diameter was found under the atrophic triceps muscle and tendon. It consisted of several greater and lesser cysts filled with a dense yellow-white fluid. There was a connection between the bursa and the posterior part of the joint capsule that necessitated removal of part of the capsule. The wound healed without complication, and function of the elbow returned to normal. There has been no evidence of recurrence.

The patient was readmitted to hospital in January 1964. He had a painful fluctuating mass on the posterior surface of the left elbow. The skin temperature was slightly elevated. The radiograph showed a lobulated shadow of calcification above the olecranon on the

* Head: Professor A. Glauber. 


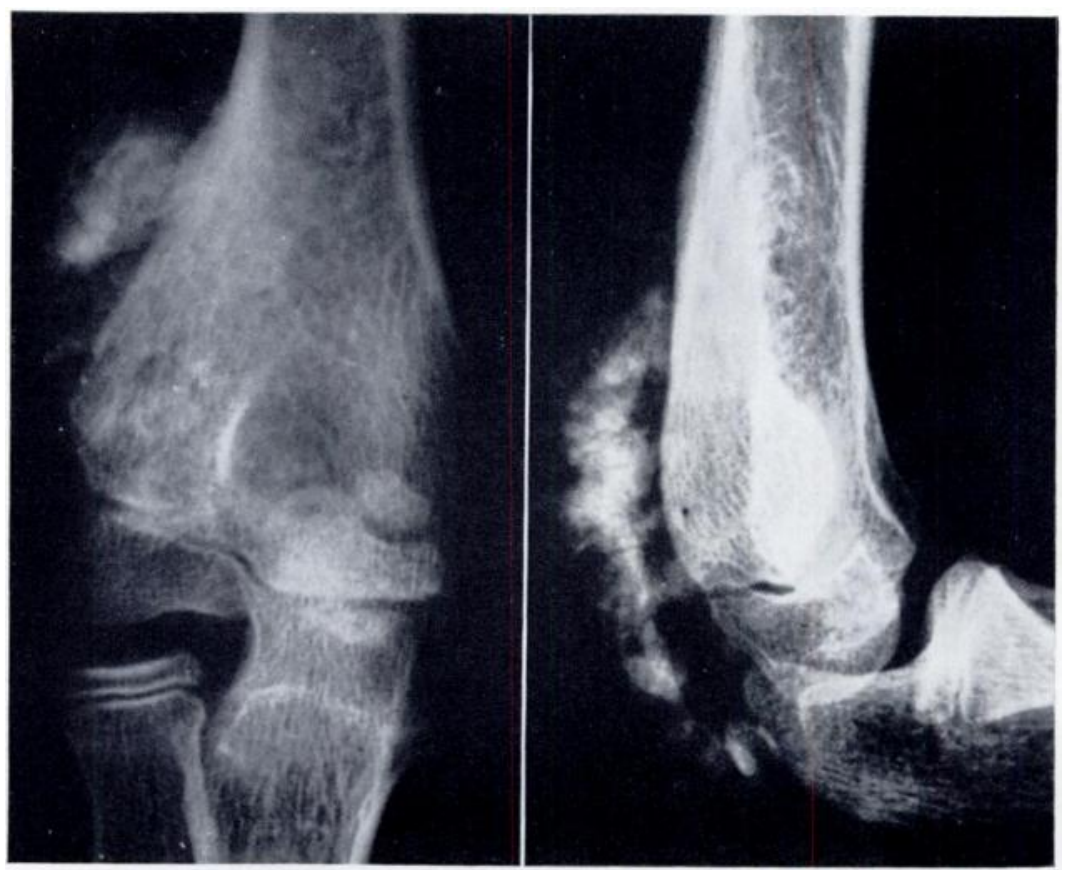

FIG. 1

Radiographs of the right elbow. Note the calcification behind and lateral to the joint.

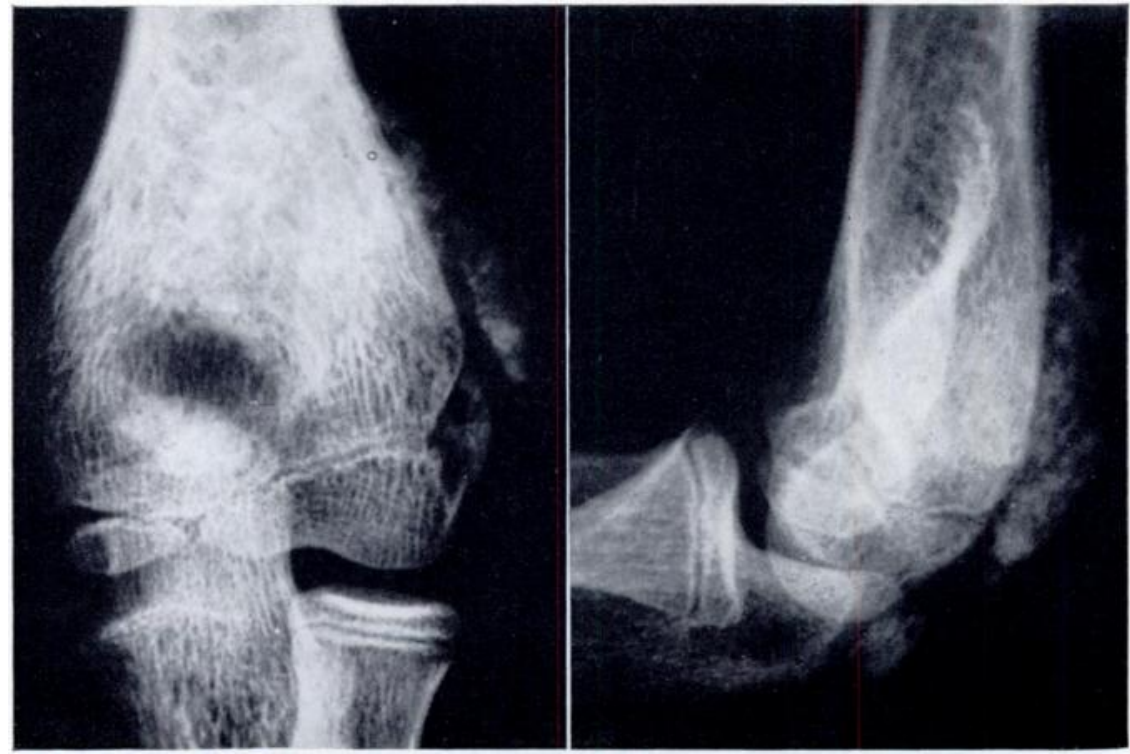

Fig. 2

Radiographs of the left elbow showing appearances similar to those in the right elbow, a year later. 
posterior surface of the humerus slightly laterally (Fig. 2). The findings at operation were similar to those in the previously affected right elbow. Eleven months later there was a recurrence with a painful fluctuating swelling in the same site. The radiograph showed a similar but

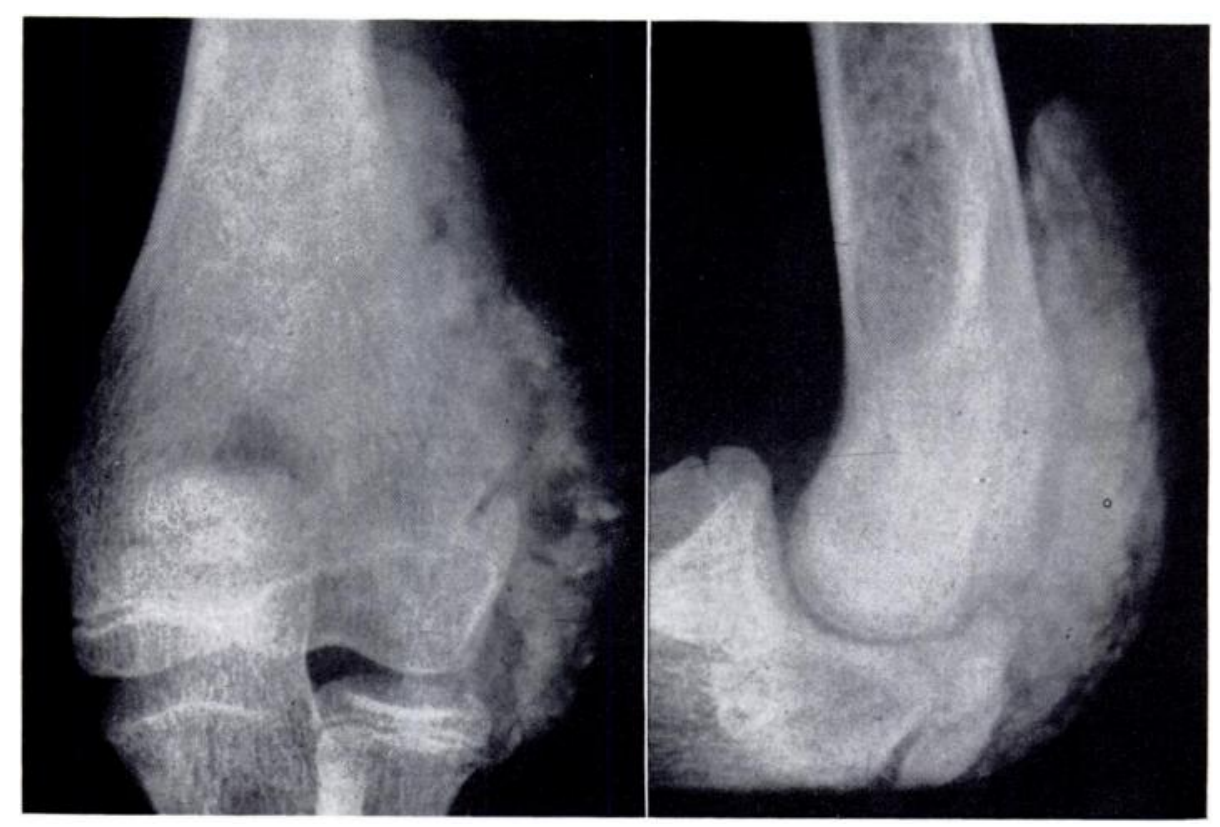

Fig. 3

Radiographs of the left elbow eleven months after operation. The area of calcification is larger than before operation.

more extensive calcification (Fig. 3). A further operation was performed in January 1965 and a lobulated bursa 4 centimetres in diameter containing yellowish-white dense fluid was excised. There has been no recurrence since that time, and there is no interference with the function of the elbow.

Biochemical findings-The calcium, phosphorus and alkaline phosphatase values (KingArmstrong) of the serum are shown in Table I. Repeated examinations showed normal

TABLE I

BIOCHEMICAL FINDINGS

\begin{tabular}{|c|c|c|c|c|}
\hline $\begin{array}{c}\text { Date of } \\
\text { examination }\end{array}$ & $\begin{array}{c}\text { Calcium } \\
\text { (milligrams per } \\
100 \text { millilitres) }\end{array}$ & $\begin{array}{c}\text { Inorganic } \\
\text { phosphorus } \\
\text { (milligrams per } \\
100 \text { millilitres) }\end{array}$ & $\begin{array}{c}\text { Alkaline } \\
\text { phosphatase } \\
\text { (King-Armstrong } \\
\text { units) }\end{array}$ & $\begin{array}{c}\text { Total } \\
\text { protein } \\
\text { (milligrams per } \\
100 \text { millilitres) }\end{array}$ \\
\hline October 1961 & $10 \cdot 8$ & $7 \cdot 0$ & $7 \cdot 7$ & $7 \cdot 35$ \\
\hline July 1962 & $11 \cdot 4$ & $6 \cdot 8$ & $9 \cdot 1$ & $7 \cdot 29$ \\
\hline January 1964 & $10 \cdot 2$ & $4 \cdot 8$ & $10 \cdot 3$ & 6.94 \\
\hline January 1965 & $10 \cdot 8$ & $7 \cdot 0$ & $9 \cdot 7$ & $7 \cdot 88$ \\
\hline April 1965 & $10 \cdot 7$ & $7 \cdot 8$ & $14 \cdot 3$ & $8 \cdot 47$ \\
\hline
\end{tabular}

calcium but an elevated level of serum phosphorus. The alkaline phosphatase values were slightly elevated. Urinary calcium and phosphorus values were normal. Total urinary calcium in twenty-four hours was 58 milligrams; inorganic phosphate was 360 milligrams. 
Blood sedimentation rate was 6 to 14 millimetres in one hour. Latex fixation test was negative. The antistreptolysin titre was 200 units. Eight millilitres of dense yellowish-white coagulate with high sedimentation rate were obtained from the bursa removed at the last operation. The quantity of this material made a more precise chemical analysis possible. The ingredients were as follows: organic material $39 \cdot 7$ per cent; inorganic material $60 \cdot 3$ per cent. The inorganic material consisted of nine parts of calcium phosphate and one part of calcium carbonate.

Histological examination-The egg-shaped, dense grey-reddish specimens 3 to 5 centimetres long showed similar pathological changes. Cavities of varying size separated by fibrous walls could be seen on the cut surface. The system of cavities was filled by a dense yellowish-grey fluid containing fine granules like sand. The composition of these granules could be seen on microscopical examination with low magnification. The outer wall, 3 to 8 millimetres thick, consisted of dense fibrous connective tissue and striated muscle bundles. Within this stratum

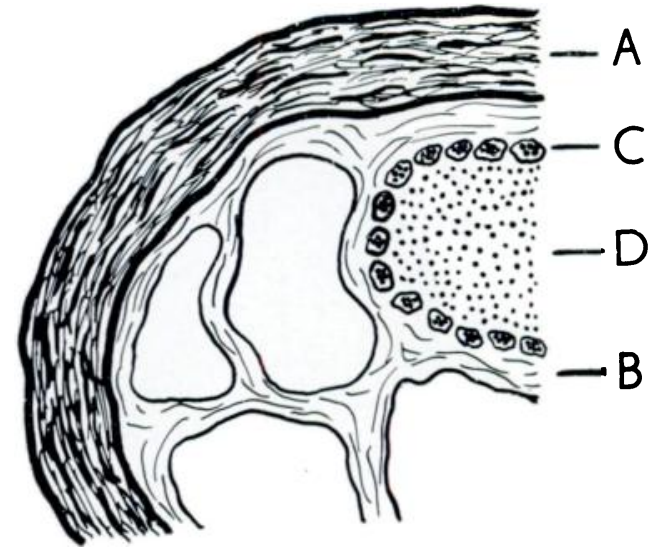

FIG. 4

Diagram of the bursa. The outer wall (A) consists of dense fibrous connective tissue and bundles of striated muscle fibres. The dividing inner septum (B) is built up of loose fibrous connective tissue. There are giant cells (C) and basophil clusters (D). several irregular cavities were found with diameters of 1 to 5 millimetres. The cavities were divided by thin septa forming an inner wall (Fig. 4). This inner wall was lined by giant cells in one or more layers. The cavity was filled with basophil staining clusters (Fig. 5). The

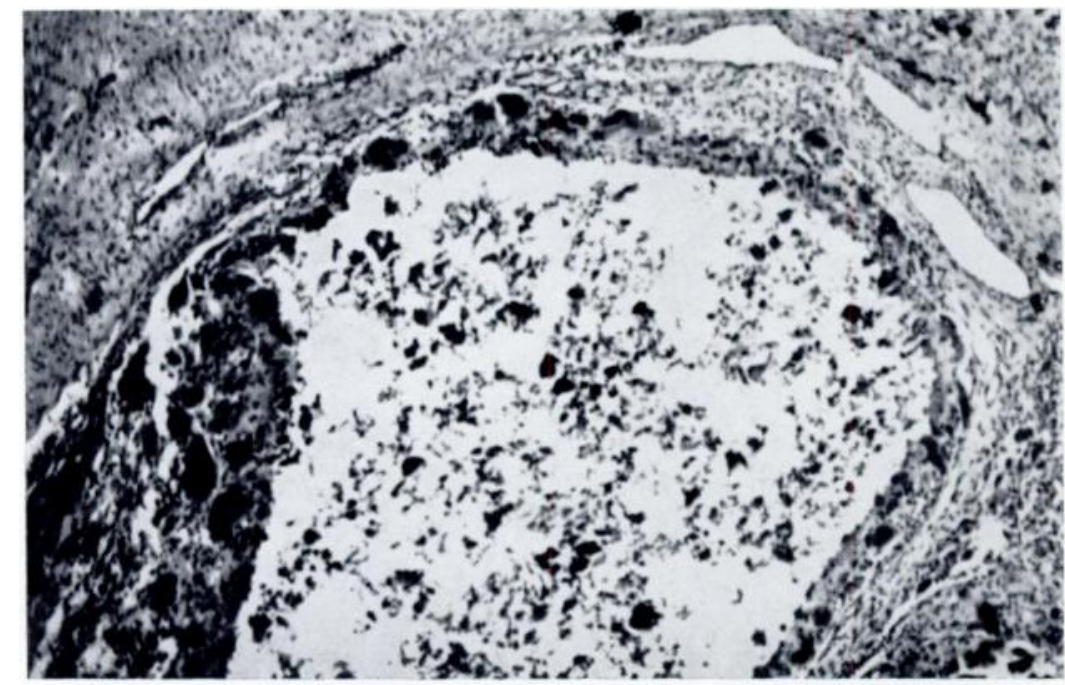

Fig. 5

Histological appearances. The inner wall is lined by one or several layers of giant cells. The lumen is filled with amorphous basophil clusters. (Haemotoxylin and eosin, $: 18$.

connective tissue of the inner wall was frequently oedematous, its structure in certain areas showing villous or papillary arrangement. The thin collagenous fibre bundles were arranged in the axis of the septa. In the zone lining the cavity multinuclear giant cells in one or more layers could be seen. The protoplasm was eosinophilic. The nuclei were generally circular:

VOL. 50 B, NO. 3, AUGUST 1968 
their number varied between ten and thirty and they were often concentrated eccentrically. A change of the structure of the surface towards the lumen into sand-like fine basophil clusters could frequently be observed, together with a basophil change of the protoplasm of the

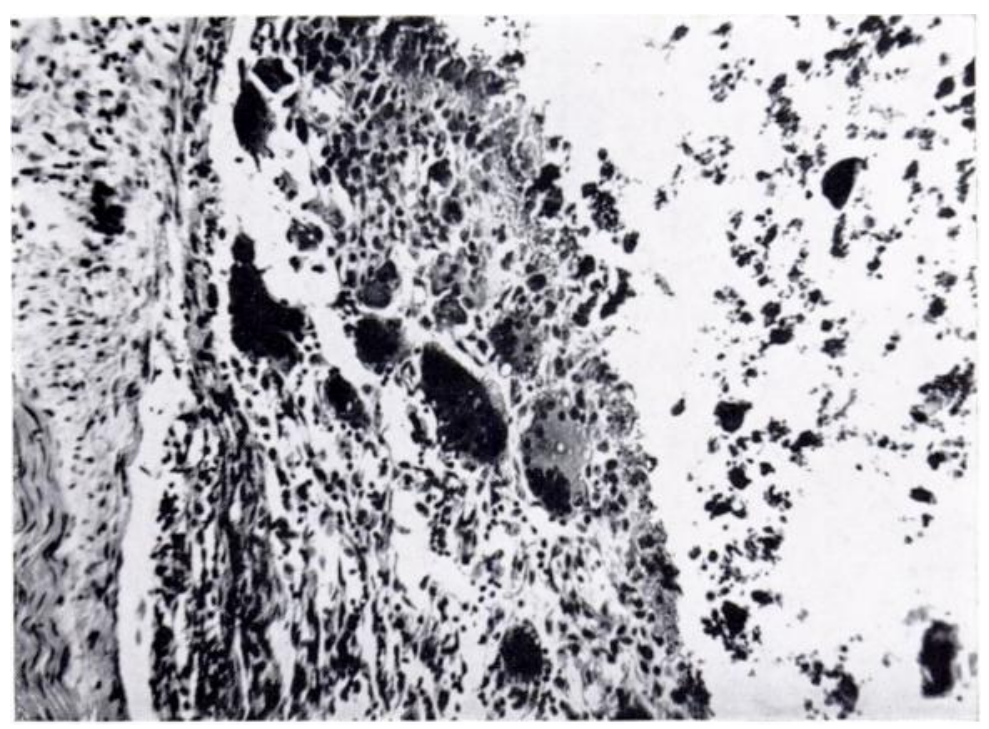

Fig. 6

The inner wall consists of loose cellular fibrous connective tissue with multinuclear giant cells. There are calcium clusters in the lumen. (Haematoxylin and eosin, $\times 40$.)

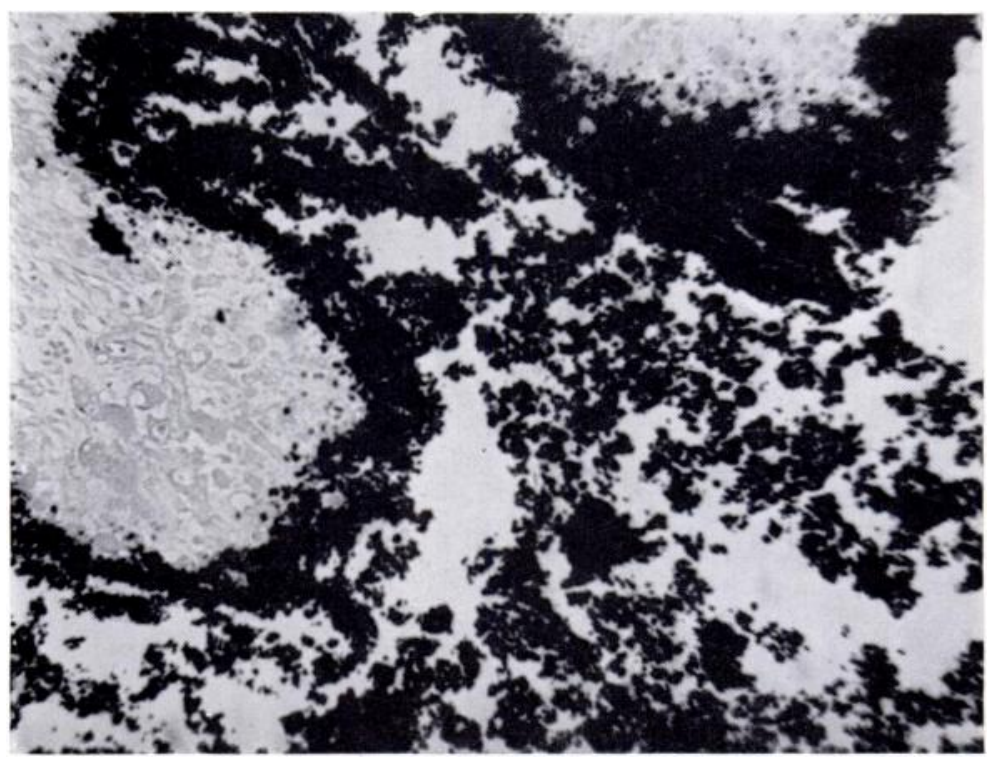

FIG. 7

The border zone of the inner wall. Positive calcium reaction by the protoplasm of the giant cells and by the clusters filling the lumen. (Kossa-reaction, $\because 40$.)

giant cells and lack of staining of the nuclei. Calcified giant cells were shed into the lumen as larger ovoid clusters (Fig. 6). The cavities were filled by amorphous dust in smaller or larger, often concentric, clusters having a positive calcium reaction (Fig. 7). 
In the loose connective tissue of the inner wall sections of cut and dilated capillaries could often be seen with a stratiform structure encircling and enveloping the cavities in the form of a well differentiated zone of hyperaemia.

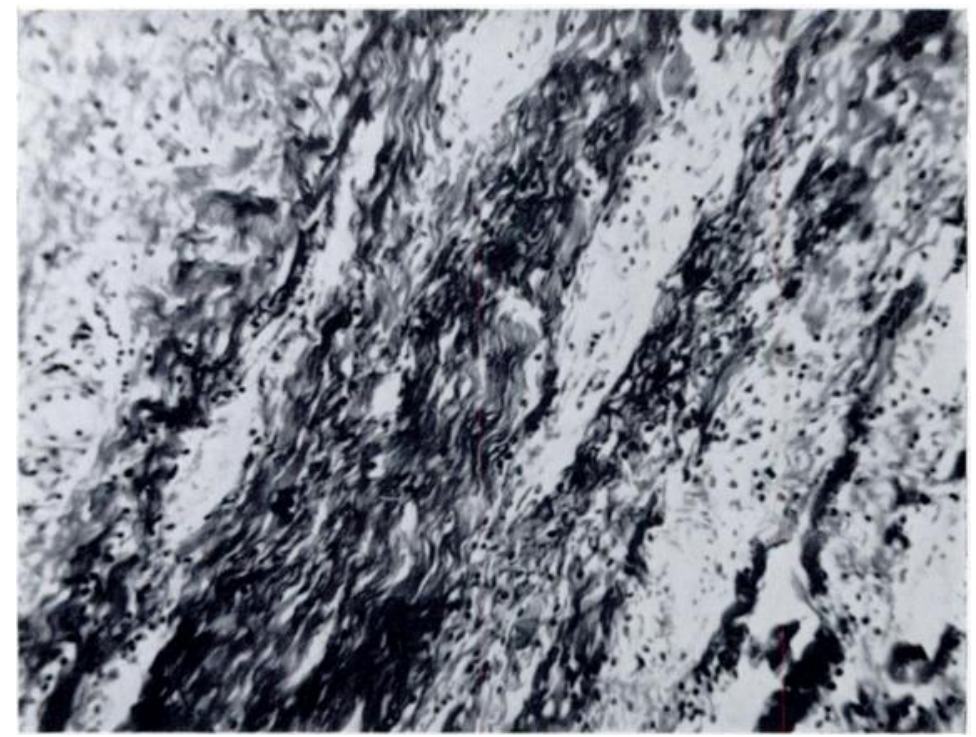

FIG. 8

Hyalin transformation of the collagen fibrous bundles of the outer wall. (Van Gieson, $\times 40$.)

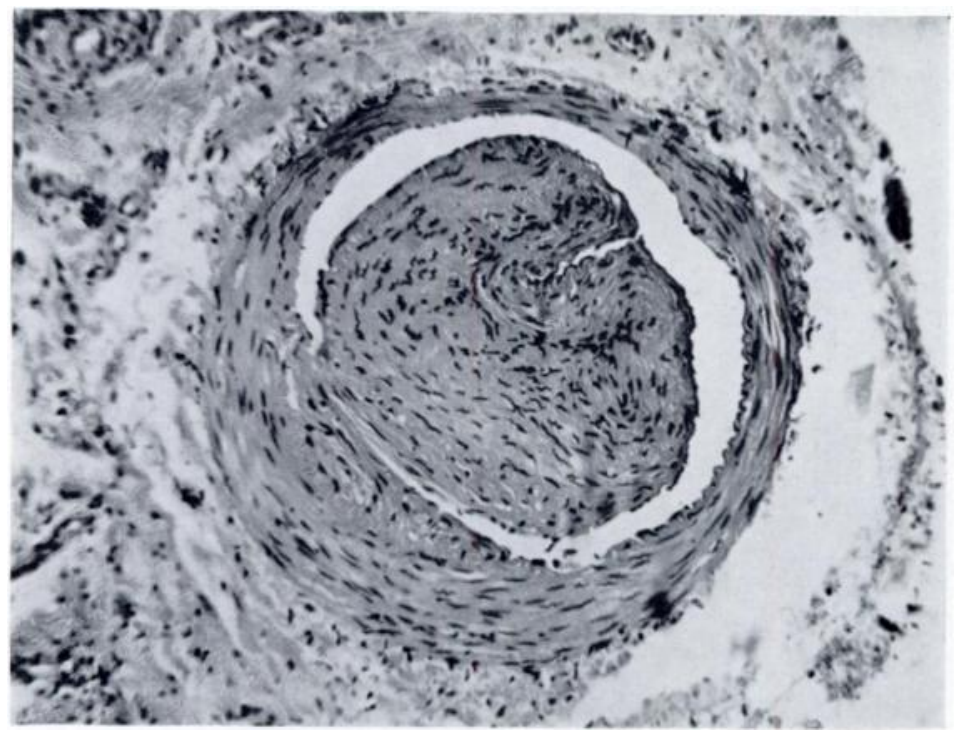

FIG. 9

Recanalised artery of the outer wall containing organised thrombus. (Haematoxylin and eosin, $\times 40$.)

Infiltrations of perivascular lymphocytes and plasma cells could also be seen in the stroma of the inner wall, even among the outer wall's bundles of connective tissue. At the junction of the outer and inner walls there were conglomerates of brown pigment clusters that stained with Prussian blue. The more dense collagen bundles of the outer wall were broken up in 
some places, and they stained red with Van Gieson (Fig. 8). In the same region the intima and the media of arteries became thicker. Recanalised vessels with organised thrombi were found (Fig. 9). The striated muscle-bundles in the neighbourhood were broken up. The muscle fibres showed an intense homogeneous bright colour on staining with Azan. The connective tissue of the perimysium internum was more voluminous. A greater than normal quantity of the bright red stained neutral mucopolysaccharides in the loose connective tissue of the inner wall could be shown by Ritter-Oleson's combined histochemical method. There was a similar reaction of a significant part of calcium clusters in the lumen and calcifying giant cells too (Fig. 10). The fibres of the inner wall, the protoplasm of the giant cells, the wall of the vessels, especially the adventitia, showed an intensive orange red colour with

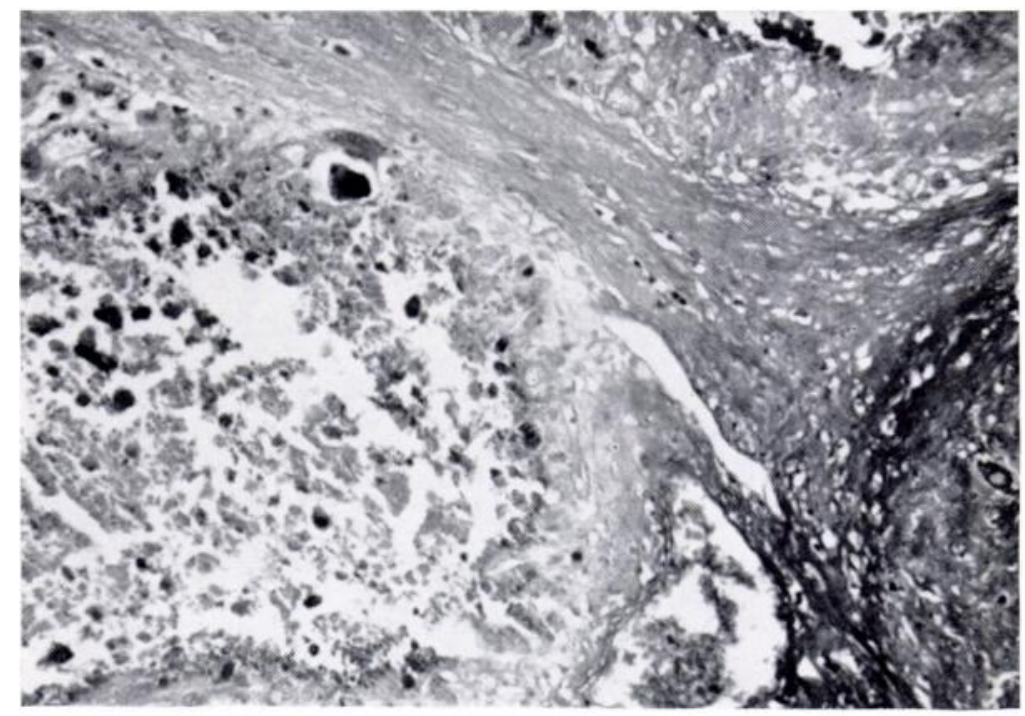

FiG. 10

Multiplication of neutral mucopolysaccharides (the lighter areas) in the inner wall. (Ritter-Oleson, 32.)

tetrazotised benzidine reaction. The protoplasm of the giant cells, the inner calcified border of the cavities, and the calcium clusters showed a more intensive staining with ninhydrin reaction, whereas the connective tissue of the outer and inner walls showed a fainter colour. Benzidine reaction was generally more intensive than that in control sections of normal connective tissue; the ninhydrin reaction on the other hand was fainter.

\section{DISCUSSION}

Although inflammation of the olecranon bursa is so frequent among miners as to be considered an occupational disease, calcification of the bursa is rare. The literature available contains only references to calcification of the olecranon bursa, and there are few descriptions of calcification in the region of the elbow such as calcium deposits near the lateral epicondyle (Bánki 1964). A decisive role was attributed to mechanical factors by Hohmann (1949), Howorth (1952) and Matzen (1959) in the etiology of olecranon bursitis, but these authors did not mention calcifying bursitis. Symmetrical and multiple bursitis is also described. Günther (1913) mentions inflammatory and rheumatic factors and assigns a role to constitutional, neural and hormonal factors too. In our case a bilateral calcareous bursitis developed in the same situation and grew to the same size on each side. The one on the left was seen five years after the onset of symptoms and three years after healing of the bursitis on the right side. A recurrence occurred on each side after excision. 
The temperature of the skin of the hands can be related to the rudimentary cervical rib. A change in the vegetative innervation by itself may also cause circulatory disturbance without mechanical troubles caused by the cervical rib.

The calcification starts in circumscribed areas 0.1 to 0.5 millimetre in diameter in association with rows of giant cells (Fig. 11). The basophilic amorphous material breaks up and a pseudocyst of microscopical dimensions develops. In the protoplasm of the giant cells of the inner wall fine calcium granules appear. After complete calcification these are thrown down and get into the constantly enlarging lumen. Their place is occupied by the ring of newly developed giant cells. This growth of the cavities can be followed to a size of 0.5 to 1 centimetre, indicating the genesis of multilocular calcified cysts. Vascular disturbance leads

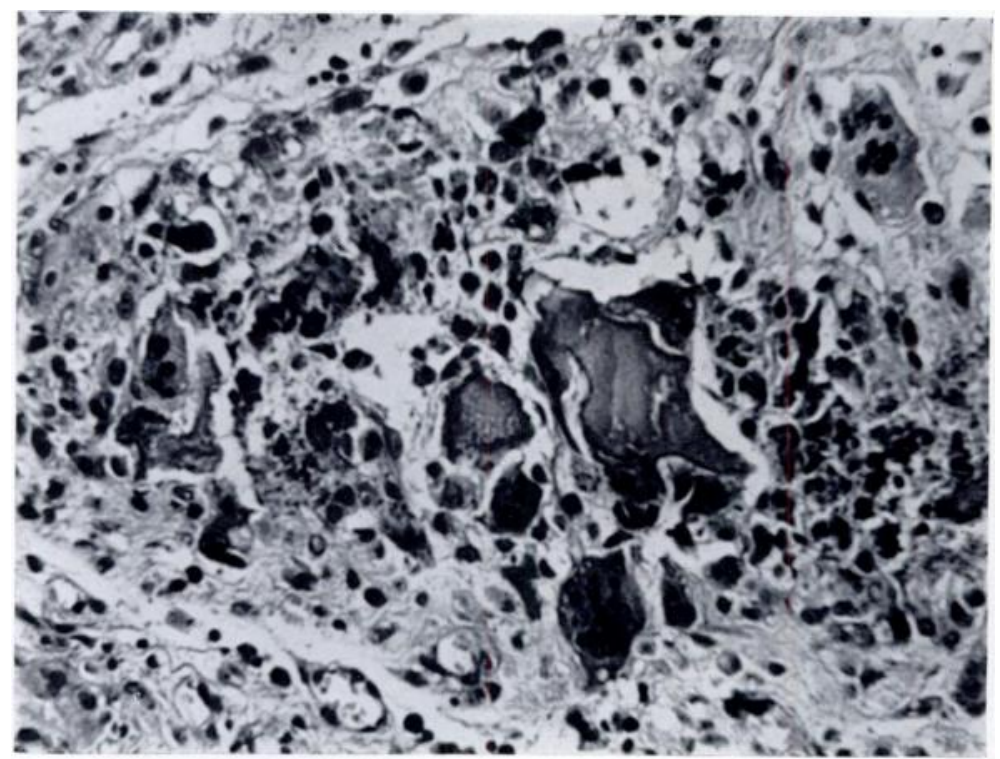

Fig. 11

Initial phase of development of the cysts. Note the amorphous calcium clusters in the intercellular substance, surrounded by giant cells and fibroblasts. (Haematoxylin and eosin, 60 .)

to tissue ischaemia. The insufficiently oxygenised tissues are very favourable spots for the deposition of calcium salts. The calcified material on the other hand as a foreign body induces a giant-cell reaction and a ring of giant cells develops, insulating the relatively intact and the necrosed areas. Later, calcium salts are taken up by the giant cells which after necrosis get in the lumen. In this way the lumen gradually enlarges. A zone of hyperaemia can be observed only around larger cavities and its development is probably a secondary phenomenon, whereas the perivascular and diffuse round cell infiltrations combined with the presence of calcium salts are a reactive phenomenon.

The progressive calcification is shown both by clinical and microscopical signs. The symmetrical appearance, the circulatory disturbance and the disturbance of phosphorous metabolism show the role of neurotrophic and metabolic factors in the genesis of calcifying bursitis. Chemical analysis of the contents of the bursa showed features similar to those observed in dystrophic calcifications.

\section{SUMMARY}

1. A case of symmetrical bilateral calcareous bursitis at the elbow is described.

2. Metabolic and neurotrophic factors played a role in its genesis.

VOL. 50 B, NO. 3, AUGUST 1968 
3. Chemical analysis showed a similarity between the ratio of calcium phosphate and calcium carbonate in dystrophic calcification and in the fluid in the bursal cavity.

4. An inflammatory reaction was seen around the calcium appearing interstitially: this was probably not a consequence of chemical stimuli.

We express our gratitude for the chemical analysis to Institute of Pharmaceutic Chemistry, Budapest. (Head: Professor Dr Antal Vegh.)

\section{REFERENCES}

Albertini, A. v. (1929): Spezielle Pathologie der Sehnen, Sehnenscheiden und Schleimbeutel. In Handbuch der speziellen pathologischen Anatomie und Histologie IX/i: F. Henke and O. Lubarsch, p. 508. Berlin: Verlag von Julius Springer.

Anderson, W. A. D., ed. (1961): Pathology. Fourth edition. St Louis: The C. V. Mosby Company.

BÁNKI, Z. (1964): Über die paraepikondylären Gebilde im Ellbogengelenk. Fortschritte auf dem Gebiete der Röntgenstrahlen und der Nuklearmedizin, 101, 501.

Claessens, H., and Faure, J. (1963): Bursites. Synovites. Ténosynovites. Acta Orthopaedica Belgica, 29, 70.

EUfINGER, H. (1957): Über Schleimbeutelverletzungen und -erkrankungen. Medizinische Klinik, 52, 1871.

ExNER, G. (1957): Muskel- und Bindegewebserkrankungen. In Handbuch der Orthopädie I: G. Hohmann, M. Hackenbroch and K. Lindemann, p. 480. Stuttgart: Georg Thieme Verlag.

Gaule, J. (1895): Der Einfluss des Nervensystems auf die Wachsthumserscheinungen in den Muskeln. Deutsche medizinische Wochenschrift, 21, 725.

GüNTHER, H. (1913): Über multiple symmetrische Erkrankungen der Sehnenscheiden und Schleimbeutel, besonders die Hygromatosis rheumatica. Deutsches Archiv für klinische Medizin, 111, 252.

Hamilton, A. R. (1951): Calcinosis. Journal of Bone and Joint Surgery, 33-B, 572.

Hohmann, G. (1949): Hand und Arm. Munchen: J. F. Bergmann Verlag.

Holzweissig, M. (1925): Über multiple, symmetrische Erkrankungen der Sehnenscheiden und Schleimbeutel. Mitteilungen aus den Grenzgebieten der Medizin und Chirurgie, 38, 605.

Howorth, M. B. (1952): A Textbook of Orthopaedics. Philadelphia and London: W. B. Saunders Company.

Katthagen, A. (1949): Das Krankheitsbild der Calcinosis und einer erstmalig beobachteten besonderen Verlaufsform, der Calcinosis segmentalis congenita. Zeitschrift für Orthopädie und ihre Grenzgebiete, 78, 543.

Markó, D. (1956): Periarthritis calcarea a kéz izületein. Orvosi hetilap, 97, 604.

Matzen, P. F. (1959): Geschwülste im Ellbogenbereich. In Handbuch der Orthopädie III: G. Hohmann, H. Hackenbroch and K. Lindemann, p. 413. Stuttgart: Georg Thieme Verlag.

MEYER, P. (1927): Dystrophische Muskelverkalkung und -verknöcherung (" Myositis ossificans neurotica ") und "kalkmetastasen" der Nieren nach Querschnittsläsion des Rückenmarks. Bruns' Beiträge zur klinischen Chirurgie, 138, 233.

Rabl, C. R. H. (1923): Zum Problem der Verkalkung. Virchow's Archiv für pathologische Anatomie und Physiologie und für klinische Medizin, 245, 542.

Reischauer, F. (1958): Zur Pathogenese der Epicondylitiden. Langenbecks Archiv für klinische Chirurgie, 289, 401.

RossaK, K. (1961): Ein Beitrag zur Myositis ossificans circumscripta neurotica. Zeitschrift für Orthopädie und ihre Grenzgebiete, 94, 576.

SeIfert, E. (1930): Schleimbeutel. In Die Chirurgie 2, p. 1409. Edited by M. Kirschner and O. Nordmann. Berlin und Wien: Urban \& Schwarzenberg.

WASCHUlEWSKI, H. (1963): Zur Funktion des periostalen desmalen Ossifikationssystems. Langenbecks Archiv für klinische Chirurgie, 302, 810. 